Mean (1.96 SE) serum cholesterol concentrations in people in Tromso aged 20-59 correlated with consumption of coffee and method of brewing

\begin{tabular}{|c|c|c|c|c|c|c|c|c|}
\hline \multirow[b]{2}{*}{$\begin{array}{l}\text { Cups of coffee } \\
\text { each day }\end{array}$} & \multicolumn{4}{|c|}{ Men } & \multicolumn{4}{|c|}{ Women (menstruating) } \\
\hline & $\begin{array}{c}\text { Boiled } \\
(n=6807)\end{array}$ & $\begin{array}{c}\text { Filter } \\
(\mathrm{n}=2228)\end{array}$ & $\begin{array}{c}\text { Instant } \\
(n=224)\end{array}$ & $\begin{array}{c}\text { All } \\
(\mathrm{n}=10030)^{\star}\end{array}$ & $\begin{array}{c}\text { Boiled } \\
(\mathrm{n}=5417)\end{array}$ & $\begin{array}{c}\text { Filter } \\
(\mathbf{n}=1620)\end{array}$ & $\begin{array}{l}\text { Instant } \\
(\mathrm{n}=168)\end{array}$ & $\underset{(\mathrm{n}=7982) \dagger}{\text { All }}$ \\
\hline $\begin{array}{l}\text { None } \\
<1 \\
1-4 \\
5-8 \\
\geqslant 9\end{array}$ & $\begin{array}{l}5.44(0.19) \\
5.73(0.05) \\
5.95(0.04) \\
6.05(0.06)\end{array}$ & $\begin{array}{l}5.47(0.24) \\
5.57(0.06) \\
5.68(0.06) \\
5.61(0.12)\end{array}$ & $\begin{array}{l}5.55(0.59) \\
5.87(0 \cdot 19) \\
5 \cdot 78(0.22) \\
6.11(0.44)\end{array}$ & $\begin{array}{l}5.38(0.08) \\
5.38(0.14) \\
5.61(0.04) \\
5.82(0.03) \\
5.90(0.05)\end{array}$ & $\begin{array}{l}5.18(0.15) \\
5.32(0.04) \\
5.44(0.04) \\
5.58(0.08)\end{array}$ & $\begin{array}{l}5 \cdot 24(0 \cdot 21) \\
5 \cdot 16(0 \cdot 06) \\
5 \cdot 28(0 \cdot 07) \\
5 \cdot 26(0 \cdot 15)\end{array}$ & $\begin{array}{l}5.52(0.50) \\
5.41(0.16) \\
5.53(0.29) \\
4.93(0.52)\end{array}$ & $\begin{array}{l}5.07(0.07) \\
5.14(0.11) \\
5.22(0.03) \\
5.36(0.03) \\
5.47(0.07)\end{array}$ \\
\hline \multicolumn{9}{|c|}{ Test for equality } \\
\hline \multicolumn{9}{|c|}{ Test for linear trend $\$$ (with cups of coffee as covariate) } \\
\hline $\begin{array}{l}\text { Regression } \\
\text { coefficient } \\
t \\
\mathrm{p}\end{array}$ & $\begin{array}{c}0 \cdot 18 \\
9 \cdot 28 \\
<0 \cdot 00001\end{array}$ & $\begin{array}{l}0.05 \\
1.63 \\
0.103\end{array}$ & $\begin{array}{l}0.08 \\
0.78 \\
0.437\end{array}$ & $\begin{array}{l}0.15 \\
13 \cdot 05 \\
<0.00001\end{array}$ & $\begin{aligned} & 0 \cdot 13 \\
& 6 \cdot 47 \\
< & 0 \cdot 00001\end{aligned}$ & $\begin{array}{l}0.06 \\
1.66 \\
0.098\end{array}$ & $\begin{array}{c}-0.09 \\
-0.84 \\
0.404\end{array}$ & $\begin{aligned} & 0 \cdot 10 \\
& 9 \cdot 19 \\
&< 0 \cdot 00001\end{aligned}$ \\
\hline
\end{tabular}

*Including 27 who drank decaffeinated coffee.

tIncluding 40 who drank decaffeinated coffee.

łAdjusted for age, body mass index, number of cigarettes smoked a day, salt and fat intakes, and physical activity in leisure time. (One way analysis of covariance.)

SAdjusted for age, body mass index, number of cigarettes smoked a day, salt and fat intakes, and physical activity in leisure time. (Multiple regression analysis.)

A concern has been that different studies of this association have yielded differing results. ${ }^{4}$ It was previously suggested that methods of brewing coffee might have a role.' This was later supported by two trials, ${ }^{23}$ and the present study shows that consumption of boiled coffee was the main explanation for the strong association previously reported.' ${ }^{1}$ The association was not significant for the other methods of brewing. The numbers of people who drank instant or decaffeinated coffee were too small to give good estimates of possible effects.

We suggest that coffee contains one or more sub- stances that affect the metabolism of cholesterol and that the length of time that the coffee grounds are in hot water determines the extent of the effect.

The coffee-cholesterol association may be mainly a Nordic problem because of the high consumption of coffee and the methods of brewing coffee in this part of the world. It is interesting, therefore, that part of the decline in serum total cholesterol concentrations in Finns has been ascribed to the changes in methods of brewing coffee that have taken place since the late 1960 s. ${ }^{5}$ Even if the effect of coffee in raising cholesterol concentrations seems small from a clinical point of view, a reduction of the mean cholesterol concentration of the population by $5-7 \%$ would reduce the incidence of coronary heart disease by $10-15 \%$. Thus encouraging people to reduce their consumption of coffee and to change their methods of brewing it may represent a new tool in preventive cardiology.

This study was supported by the Norwegian Council on Cardiovascular Disease, the Norwegian Research Council for Science and Humanities, and the Aakre Foundation.

1 Thelle DS, Arnesen E, Førde OH. The Tromsø heart study. Does coffee raise serum cholesterol? N Engl f Med 1983;308:1454-7.

2 Førde OH, Knutsen SF, Arnesen E, Thelle DS. The Tromsø heart study: coffee consumption and serum lipid concentrations in men with hypercholesterolaemia. A randomised intervention study. Br Med f 1985;290: 893-5.

3 Aro A, Tuomilehto J, Kostianien E, Uusitalo U, Pietien P. Boiled coffe increases serum low-density lipoprotein concentration. Metabolism 1987;36: $1027-30$.

4 Thelle DS, Heyden S, Fodor JG. Coffee and cholesterol in epidemiological and experimental studies. Atherosclerosis 1987;67:97-103.

5 Tuomilehto J, Tanskanen A, Pietinen P, et al. Consumption of coffee is correlated with serum cholesterol in middle-aged Finnish men and women. f Epidemiol Community Health 1987;41:237-42.

(Accepted 11 fuly 1988)
Sheikh Rashid Diabetes

Unit, Radcliffe Infirmary,

Oxford

R N Baldwin, MRCP, research fellow

T D R Hockaday, FRCP, consultant physician

\section{Immunodiagnostic}

\section{Research}

Laboratory, University of

Birmingham, Birmingham

C Mijovic, PHD, research

fellow

A R Bradwell, FRCP, senior

lecturer

Department of Medicine,

East Birmingham Hospital,

Birmingham B9 5ST

J Fletcher, MRCP, MRC

training fellow

A H Barnett, MD, senior

lecturer

Correspondence to: Dr Barnett.

\section{Immunoglobulin heavy chain phenotypes and background retinopathy in non-insulin dependent diabetics}

\author{
R N Baldwin, C Mijovic, J Fletcher, \\ A R Bradwell, A H Barnett, T D R Hockaday
}

Immunological factors may play a part in diabetic microangiopathy.' An association of HLA-B8, HLA$B 15$, and HLA-DR4 with retinopathy has been described in insulin dependent diabetes but has not been confirmed. ${ }^{1}$ An association between the HLA-B3 allotype of the $\mathrm{C} 4$ component of complement and retinopathy has also been reported. ${ }^{1}$ As this component is also encoded within the HLA region and is important in the humoral response immunoglobulin genes have also been studied. The allotype markers on human IgG, the Gm markers, are located within the constant regions of the heavy chain and encoded on chromosome 14. Retinopathy and the Gm (zaf;n;bg) phenotype are associated in insulin dependent diabetics. ${ }^{2}$ As development of microangiopathy is probably similar in non-insulin dependent and insulin dependent diabetes we have studied the relation between retinopathy and $\mathrm{Gm}$ phenotypes in noninsulin dependent diabetics.

\section{Patients, methods, and results}

The patients comprised 110 patients who had been recruited to the Oxford prospective study of noninsulin dependent diabetes during 1973-6 who had been followed up from entry and in whom colour photographs of the retina were taken in 1982 and 1985, seven and 10 years after diagnosis respectively. The patients were of European white origin.

Samples of plasma were collected into edetic acid and frozen at $-20^{\circ} \mathrm{C}$ for subsequent identification of the $\mathrm{Gm}$ phenotype on standard haemagglutination inhibition assay. ${ }^{2}$ Heavy chain markers typed were: Glm (z), Glm (a), Glm (x), and Glm ( $f$ ) in IgG subclass 1 ; G2m (n) in subclass 2; and $\mathrm{G} 3 \mathrm{~m}(\mathrm{bl})$ and $\mathrm{G} 3 \mathrm{~m}(\mathrm{~g})$ in subclass 3 . This permitted identification of the common haplotypes of European white people $\mathrm{Gm}$ (za;g), Gm (zax;g), Gm (f;b), and $\mathrm{Gm}(\mathrm{f} ; \mathrm{n} ; \mathrm{b})$. The typing was performed after analysis of the retinal photographs.

Statistical analysis was performed with the statistical package for the social sciences (SPSS). The differences in the frequencies of the Gm phenotypes between patients with and without retinopathy were analysed

Number (percentage) of patients with and without retinopathy seven and 10 years after diagnosis of non-insulin dependent diabetes, according to $\mathrm{Gm}$ phenotype

\begin{tabular}{|c|c|c|c|c|}
\hline \multirow[b]{2}{*}{ Gm phenotype ${ }^{\star}$} & \multicolumn{2}{|c|}{ Seven years after diagnosis } & \multicolumn{2}{|c|}{ Ten years after diagnosis } \\
\hline & $\begin{array}{l}\text { Without } \\
\text { retinopathy } \\
(n=67)\end{array}$ & $\begin{array}{l}\text { With } \\
\text { retinopathy } \\
(n=43)\end{array}$ & $\begin{array}{l}\text { Without } \\
\text { retinopathy } \\
(\mathrm{n}=22)\end{array}$ & $\begin{array}{c}\text { With } \\
\text { retinopathy } \\
(\mathrm{n}=88)\end{array}$ \\
\hline$f ; n ; b$ & $22(33)$ & $12(28)$ & $12(55)$ & $22(25)$ \\
\hline zax;g & $5(7)$ & $1(2)$ & $1(5)$ & $5(6)$ \\
\hline zafx;n;bg & $4(6)$ & $16(37) \dagger$ & & $20(23)$ \\
\hline zaf;n;bg & $15(22)$ & $5(12)$ & $3(14)$ & $17(19)$ \\
\hline zaf;bg & $6(9)$ & $7(16)$ & $1(5)$ & $12(14)$ \\
\hline$z a f x ; b g$ & $3(4)$ & $1(2)$ & & $4(5)$ \\
\hline$f ; b$ & $6(9)$ & & $4(18)$ & $2(2)$ \\
\hline$z a ; g$ & $2(3)$ & & & $2(2)$ \\
\hline
\end{tabular}

*Additional phenotypes zaf;b, za;n;bg, zf;n;b, fx;n;b, and zax;n;g (each identified in only one patient) were not shown. $t x^{2}=17 \cdot 2$, corrected $\mathrm{p}<0 \cdot 01$. 
by the $\chi^{2}$ test. $p$ Values were corrected for the number of tests performed by multiplying by the number of phenotypes compared.

Seven years after diagnosis of diabetes 43 of the 110 patients had retinopathy and by 10 years this had risen to 88. The table shows the relation between retinopathy and the $\mathrm{Gm}$ phenotypes. The frequency of the phenotype $\mathrm{Gm}$ (zafx;n;bg) was significantly higher in the group with retinopathy than that without $(37 \%(16 /$ 43) $v 6 \%(4 / 67), \mathrm{p}<0.001$, corrected $\mathrm{p}<0.01)$ at the seven year review; there was no other significant association. At the 10 year review no significant differences were detected. By this time, however, only 22 of the original cohort remained free of retinopathy. All of the 20 patients with the phenotype $\mathrm{Gm}$ (zafx;n;bg) had retinopathy.

\section{Discussion}

The phenotype $\mathrm{Gm}$ (zaf;n;bg) associated with retinopathy in insulin dependent diabetics ${ }^{2}$ was not associated with non-insulin dependent diabetics, but the photographs taken at the seven year review showed that retinopathy was associated with phenotype $\mathrm{Gm}$ (zafx;n;bg). Furthermore, by the 10 year review all 20 of the patients with this phenotype had retinopathy. These two heterozygous phenotypes differ only in the $x$ allotype, which is characterised by the substitution of glycine for alanine at position 431 of the constant region of the heavy chain. ${ }^{4}$

Both phenotypes identified in the previous ${ }^{2}$ and the present study were heterozygous. Heterozygosity may confer an enhanced immune response, but this could be confirmed only by family studies. Evidence suggests that an amplified immune response to bacterial antigen is conferred by heterozygosity for the Gm allotype. ${ }^{5}$ This may lead to increased concentrations of circulating immune complexes, which have been reported in patients with microangiopathy.'

Our findings support a possible association of heavy chain immunoglobulin phenotypes with early development of retinopathy in non-insulin dependent diabetics. The findings in both insulin dependent and non-insulin dependent diabetics suggest that this complication may have an immunogenetic component, which may help to identify diabetics predisposed to microangiopathy.

CM was supported by the British Diabetic Association and by Ames Laboratories.

1 Mijovic C, Barnett AH. Immunogenetics of diabetic microangiopathy. In Barnett AH, ed. Immunogenetics of insulin dependent diabetes. Lancaster: MTP Press, 1987:111-20

2 Mijovic C, Fletcher JA, Bradwell AR, Barnett AH. Phenotypes of the heavy chains of immunoglobulins in patients with diabetic microangiopathy: evidence for an immunogenetic predisposition. Br Med f 1986;292:433-5.

3 Hockaday TDR, Hockaday JM, Mann JI, Turner RC: Prospective comparison of modified fat and low carbohydrate dietary advice in the treatment of diabetes. Br $\mathcal{F}$ Nutr 1978;39:357-62.

4 Schanfield MS, Van Loghem E. Human immunoglobulin allotypes. In: Weir DM, ed. Handbook of experimental immunology. Vol 3. Genetics and molecular immunology. 4th ed. Oxford: Blackwell Scientific Publications, 1986:94.1 4.18.

5 Whittingham S, Mathews JD, Schanfield MS, et al. Interactive effect of Gm allotypes and HLA- locus antigens on the human antibody response to a bacterial antigen. Clin Exp Immunol 1980;40:8-15.

(Accepted 14 fuly 1988)

\title{
Antibody to Saccharomyces cerevisiae (bakers' yeast) in Crohn's disease
}

\author{
Janice Main, Hamish McKenzie, \\ Grant R Yeaman, Michael A Kerr, \\ Deborah Robson, Christopher R Pennington, \\ David Parratt
}

Department of Medicine, King's Cross Hospital, Dundee

Janice Main, MRCP, research registrar

Christopher R Pennington, FRCP, consultant

Department of Medical Microbiology, Ninewells Hospital and Medical School, Dundee Hamish McKenzie, MB, lecturer

Deborah Robson, BSC, research assistant

David Parratt, MD, senior lecturer

Department of Pathology, Ninewells Hospital and Medical School, Dundee Grant R Yeaman, BSC, research assistant Michael A Kerr, PHD, lecturer

Correspondence to: $\mathrm{Dr} J$ Main, Department of Medicine, St Mary's Hospital, London W2 1NY.
The possible role of diet in the pathogenesis of inflammatory bowel disease has prompted several studies of the immune response to food antigens, but no specific abnormality has so far been shown in either Crohn's disease or ulcerative colitis. ${ }^{12}$ We report a study of antibody to Saccharomyces cerevisiae (bakers' yeast), a common dietary antigen, in patients with inflammatory bowel disease and in controls.

\section{Subjects, methods, and results}

We obtained blood samples from 55 patients with Crohn's disease and 40 with ulcerative colitis; the diagnosis was by standard criteria. ${ }^{3}$ Ethical approval was obtained. Control samples were obtained from 30 blood donors.

To prepare the antigen $S$ cerevisiae (dried yeast, Be-Ro) was cultured on Sabouraud agar (Oxoid) for 48 hours at $37^{\circ} \mathrm{C}$. The growth was harvested, washed, and resuspended in $0 \cdot 15 \mathrm{M}$ sterile saline. The suspension was heated at $100^{\circ} \mathrm{C}$ for one hour and diluted in $0.05 \mathrm{M}$ carbonate-bicarbonate buffer (pH 9.6) for coating plates.

Nunclon plates (Gibco) were coated with the antigen by incubation for one hour at $37^{\circ} \mathrm{C}$ and 16 hours at $4^{\circ} \mathrm{C}$. Assays were washed three times with $0.05 \mathrm{M}$ phosphate buffered saline ( $\mathrm{pH} 7 \cdot 4$ ) containing $0.01 \%$ ( $\mathrm{vol} / \mathrm{vol}$ ) Triton X-100. All serum samples were assayed in duplicate at a dilution of $1: 100$ in wash buffer. Antibody was detected with anti-IgA or anti-IgG (affinity purified) linked to alkaline phosphatase (Sigma) with $p$-nitrophenyl phosphate (Sigma) as the substrate. The plates were incubated for one hour at $37^{\circ} \mathrm{C}$. Optical densities were measured at $410 \mathrm{~nm}$ and standardised against a positive reference sample. The significance of differences in antibody titres between groups was tested by the Mann-Whitney test. ${ }^{4}$

Titres of both IgG and IgA to $S$ cerevisiae in the patients with Crohn's disease were significantly higher $(\mathrm{p}<0.001)$ than those in the controls (figure). In contrast, antibody titres in the patients with ulcerative colitis were not significantly different from those in the controls. Among the patients with Crohn's disease there was no significant difference in antibody titres between patients with disease of the small or large bowel (data not shown).

\section{Comment}

The considerable difference in titres of antibody to $S$ cerevisiae between the patients with Crohn's disease and those with ulcerative colitis contrasts with previous reports of a generalised increase in antibody to food antigens in people with inflammatory bowel disease. ${ }^{12} \mathrm{~A}$ generalised increase may reflect increased exposure to antigens owing to an inflamed or damaged bowel wall and is probably secondary to the primary disease process. In contrast, the response to $S$ cerevisiae seemed to be quite specific to Crohn's disease and cannot be easily explained as a secondary phenomenon. Furthermore, the difference between the diseases cannot be accounted for on an anatomical basis, as increased titres of antibody to $S$ cerevisiae were not confined to patients with Crohn's disease of the small bowel.

$S$ cerevisiae is unlikely to be a cause of Crohn's disease as it is not a common pathogen, though infections have been reported in immunosuppressed 